\title{
MEASURING THE LEANNESS OF SUPPLIERS USING PRINCIPAL COMPONENT ANALYSIS TECHNIQUE
}

\author{
Y. Zare Mehrjerdi ${ }^{1}$ \\ Department of Industrial Engineering \\ Yazd University, Yazd, Iran \\ Yazm2000@yahoo.com
}

\begin{abstract}
A technique that helps management to reduce costs and improve quality is 'lean supply chain management', which focuses on the elimination of all wastes in every stage of the supply chain and is derived from 'agile production'. This research aims to assess and rank the suppliers in an auto industry, based upon the concept of 'production leanness'. The focus of this research is on the suppliers of a company called Touse-Omron Naein. We have examined the literature about leanness, and classified its criteria into ten dimensions and 76 factors. A questionnaire was used to collect the data, and the suppliers were ranked using the principal component analysis (PCA) technique.
\end{abstract}

\section{OPSOMMING}

Lenige voorsieningsbestuur ("lean supply chain management") is 'n tegniek wat bestuur in staat stel om koste te verminder en gehalte te verbeter. Dit fokus op die vermindering van vermorsing op elke stadium van die voorsieningsketting en word afgelei van ratse vervaardiging ("agile production"). Hierdie navorsing poog om leweransiers in 'n motorbedryf te beoordeel aan die hand van die konsep van vervaardigingslenigheid ("production leanness"). Die navorsing fokus op leweransiers van 'n maatskappy genaamd Touse-Omron Naein. 'n Literatuurstudie aangaande lenigheid het gelei tot die klassifikasie van kriteria in tien dimensies en 76 faktore. 'n Vraelys is gebruik om die data te versamel en die leweransiers is in rangvolgorde geplaas aan die hand van die PCA-tegniek.

1 The author was enrolled for a D Phil (Industrial Engineering and Management) degree in the Department of Industrial Engineering and Management, Oklahoma State University, USA. 


\section{INTRODUCTION}

Strong competition between organisations is an obvious feature of the contemporary scene; and so every organisation, if it is to survive in this dynamic environment, needs to be customer-oriented, quality-oriented, and service-oriented. In addition, each organisation must consider cost control, quality enhancement, and price reduction. Organisations that do not follow these rules of the game are unlikely to stay in business for long. On the other hand, the mutual interdependence of organisations makes it clear that any one organisation's optimal decisions are not sufficient guarantee of that organisation's success. It is true that the efficiency of upper- and lower-stream organisations directly impacts the success of an organisation in achieving its goals and so taking the right steps toward its ultimate vision. This viewpoint has been the main reason for the introduction of the concept and philosophy known today as supply chain management. This dictates that all processes that have direct and indirect impact on the supplying of customer needs across the entire supply chain must work very closely together, and need to be regarded as a whole but complex system [7,37]. These problems have brought to the surface the important concept of suppliers' evaluation, also known as the downstream entities of organisations that are capable of enhancing the quality of their end products and final prices. Often, the evaluation of suppliers was intended to achieve better utilisation, supplier management, inventory cost reduction, and total production cost minimisation. That is why the generation of long-term competitive opportunities [28], cooperation and the enhancement of relationships with suppliers, and obtaining the best strategic members [13] are among the objectives of supplier evaluation.

In the auto industry the supply chain system is very complex, and often has many sub-systems. Due to the fact that these sub-systems vary and function differently, they have a big impact on the lead time and cost, and so reduce quality. For this reason, different strategies have evolved to reduce waste and enhance quality. One of the strategies to eliminate waste entirely is known as 'lean supply chain' [5, 16, 30]. Because the auto industry has become a relatively major one in Iran, this research is conducted to evaluate and rank the industry suppliers. Attending to this section of the supply chain as a system input, and trying to improve quality from the start, may enhance the quality of the entire chain.

\section{THEORETICAL FRAMEWORK}

Various researchers have given different definitions for lean production. Forrester's view [10] is of the integration of the principles relating to improvement through simultaneous utilisation of total quality management and ' just-in-time' (JIT) delivery so that all computer-based processes in all sections - as such as design, factory management, supply, and distribution - are optimised [10, 21]. Williams et al. [21, 33] consider lean production as a shift from mass production to a new production pattern. Lean production is also defined as a production system that considers the entire benefits of mass production and shop floors, while trying to reduce waste and eliminate any processes that generates no added value. In fact, we can say that lean production is the same as a JIT production system - except that those processes that add no value are eliminated. The pioneers of lean production system are Toyota \& Ohno [47], who struggled after World War II to generate all the substructures that are necessary for lean production. The origins of lean manufacturing can be traced to the Toyota Production System (TPS), with its focus on the reduction and elimination of waste.

In the early 1990s, Womack et al. [35] from MIT wrote about "the machine that changed the world". They defined lean production as a mixture of Ford's mass production type and the social control model of the Japanese production system. Later, this viewpoint was adopted as a strategy to enhance global competitive power. Many companies that achieved satisfactory results from implementing the lean production philosophy in their production systems tried to apply the same technique to other areas of their enterprise, such as product design, receiving and shipping processes, receivable systems, and even the entire process of supply chain system [6].

The implementation of lean principles in those companies produced satisfactory results, in that they were able to enhance the overall productivity of their organisations. As a result of accepting 
and implementing these principles, the companies could reduce waste, lead time, and delivery time to an acceptable extent; at the same time they could reduce prices and improve the quality of their products. For this reason they were able to reduce the inventory level by as much as $90 \%$, reduce reworking by up to $75 \%$, and cut delivery time by up to $90 \%$ [9]. The successes in lean production, in practice, have attracted the attention of many researchers and introduced new tools to industries that want to implement it $[4,14,17,18,26,27,34,35]$.

\section{COMPONENTS OF LEAN PRODUCTION}

Research into lean production was first conducted by Sugimori et al. [43], and continued with various examinations of this philosophy from different angles, so that its various components were taken into consideration. In articles entitled 'Processes towards lean production: The role of the management accounting system' [1] and 'A model for evaluating the degree of the leanness of manufacturing firms' [21] the methods of using lean production in different industries - including handcrafts industries - are discussed. An operations management model of lean production $[1,21]$ suggests that principles as such as (1) waste elimination, (2) permanent improvement, (3) zero defects, (4) JIT delivery, (5) pull raw material system, (6) multi-purpose teams, (7) focus teams, (8) activities integration, and (9) vertical information systems are taken into account as the foundations of lean production.

A review of the struggle to implement lean production in the production and operation management of 27 lean companies indicates that some of the areas of this production system are: processes and equipment; planning and manufacturing control; human resources; product design; and good relationships with suppliers and customers. The results of the research indicate that the main area for becoming a lean organisation is the management of external communication (i.e. with suppliers and consumers), which is even more important than the companies' internal operations [24].

Because the lean concept applies throughout the organisation, different components for leanness, such as tools and principles of leanness, are being introduced.

\section{SUPPLY CHAIN AND LEAN SUPPLY CHAIN}

The term 'supply chain' was introduced into the literature in the late 1980s, and between 1990 and 2000 it was used more extensively [11, 12, 15]. Before that time the term that was used more often was 'logistics'. This term is usually applied to all those activities that are related to the internal functions of an organisation. A supply chain, by contrast, is a network of companies that work with each other to accomplish all the tasks and activities that are necessary to deliver goods and services to the market. A supply chain is a system whose constituent parts include material suppliers, production facilities, distribution services, and customers, all linked by a feed-forward flow of materials and a feedback flow of information [44].

Lean production, originating in the Toyota production system, is one of the initiatives that many major businesses world-wide have been trying to adopt in order to remain competitive [35]. Although lean production takes into consideration the advantages of mass production and shop floor production, it tries hard to eliminate waste and any activities that do not add value to the company. So lean technology introduces many functions and responsibilities in ensuring the correctness and improvement of processes. The focus of this multi-dimensional approach is on cost-reduction by eliminating activities that do not add value, and by using tools such as JIT, cellular manufacturing, total productive maintenance, production smoothing, setup reduction, and others to eliminate waste [31], [20], [32], not only within an organisation but also along its supply chain network [29].

'Lean' is about doing more with less. The term is often used in connection with lean manufacturing [35] to imply a 'zero inventory' just-in-time approach. In practice, minimum reasonable inventory (MRI) is a more relevant philosophy [45]. Paradoxically, many companies that have adopted lean manufacturing as a business practice are anything but agile in their supply chain. The car industry illustrates this conundrum in many ways. Lean 
manufacturing is called 'lean' as it uses less, or the least, of everything that is required to produce a product or perform a service [46]. Leanness achieves this by eliminating all nonvalue adding processes [35]. In a pure lean supply chain there would be no slack and zero inventory. It would be very impressive if zero inventory throughout an entire supply chain were achieved. A more realistic view would be to aim for a minimum reasonable inventory (MRI) where any further attempts to decrease stocks would not be worthwhile [45].

The principle of the lean supply chain is that the benefits of leanness for the product do not apply only to one section of the supply chain, but are transferred to every part of the chain [16]. Thus it can be said that the focus of the lean supply chain is on the elimination of all waste and on the introduction of a fixed scheduling level for the entire chain $[23,24]$ - in other words, to run the concepts of lean product through the entire supply chain process.

\section{RESEARCH METHOD}

This is a descriptive-analytical study, with a statistical population of eight raw material suppliers of the Touse-Omron Naein company. With more than 400 employees, this company is one of the suppliers of Iran-khodro producing Mil-Lang and Mil-Badamak for various automobiles. The data for this research was gathered from that organisation's suppliers through a review and the use of questionnaires about the components of leanness. The questionnaire, with 10 components and 76 sub-components, was completed by the middle and top management of the organisation. These components were gathered from a literature review and other relevant studies, using a five-point Likert scale ranging from 'very low' to 'very high'. In this study, 'very high' means that the organisation is highly valued based upon the components in question; 'very low' means that it is not highly valued.

\section{PROPOSED MODELS FOR ASSESSMENT OF SUPPLIERS}

To assess suppliers, various components and methods are proposed so that most of them are based upon the buyer's experiences of the suppliers [22]. Some of these methods are: (1) Algebraic addition of criteria [30]; (2) Analytical Hierarchy Process [3, 19]; (3) Mathematical model of facility location [8]; (4) Stochastic models [25]; (5) Simulation models [28]; and (6) Data Envelopment Model [2, 42]. In this research, to assess and rank the suppliers, we will use the Principal Component Analysis (PCA) model.

The Principal Component Analysis tool is used many times in multivariate statistics such as factor analysis. Many researchers have used PCA for data analysis purposes. Researchers claim that the main idea for the development of the PCA goes back to the work of Pearson in 1901, expanded by Hotelling in 1933 [2, 42]. To study a specific issue in society, one needs to take $p$ variables (indices) into consideration. These variables might be dependent on one another; they might not include the same amount of information; and it is possible that some are of no value to the study. So variables must be chosen that can really distinguish one population from another. Although it is not an easy task, variables that cannot act well in this regard might need to be ignored. Meantime, the goal of PCA is the recognition of a series of new variables, where each variable is called the principal component. PCA is useful in reducing the number of variables under study, and thus ranking and analysis of decision-making units such as industries, universities, libraries, hospitals, cities, etc [36-40]. For example, PCA was used in a study for the selection of monitoring plants for fluoride [34]; it captured the measurement correlations and reconstructed each variable to define associated residuals and the sensor validity index. Rossi et al. [36] have analysed beverage data using PCA and cluster analysis. Wange et al. [37] have proposed several capability indices and quality measures for summarising process performance using PCA. Gamesalingam et al. [38] have studied financial data via multivariate statistical analysis (PCA, factor analysis, and cluster analysis). Wang et al. [41] have used three improved neural networks and PCA for air quality forecasting. Martin et al. [39] have studied manufacturing performance enhancement through multivariate statistical process control and PCA. Nagai et al. [40] have studied potential barriers to total quality management using PCA and correspondence analysis. 
As a tool, PCA has three objectives:

1. To identify a new set of variables, such that each new variable (called a principal component) is a linear combination of original variables.

2. The first new variable $y 1$ accounts for the maximum variance in the sample data, and so on.

3. The principal components (new variables) are uncorrelated.

PCA is performed by identifying either the eigen-values of the covariance or the singular value decomposition of the original data. In this study we use the former approach only.

If $L_{m i}$ shows the coefficient of $\mathrm{m}^{\text {th }}$ variable for $\mathrm{j}^{\text {th }}$ principal components then we can write

1) $L_{m 1}{ }^{2}+L_{m 2}{ }^{2}+\ldots+L_{m p}{ }^{2}=1 \quad m=1,2, \ldots, p$

2) $L_{m 1} \cdot L_{n 1}+L_{m 2} \cdot L_{n 2}+\ldots+L_{m p} \cdot L_{n p}=0$

$m \neq n$, and $n=1,2, \ldots, p$

The principal components are independent variables, and PCA is done by the recognition of the covariance special structure.

\section{STEPS IN PRINCIPAL COMPONENT ANALYSIS}

The steps to be followed are:

\section{Step 1}

Matrix $X_{k x p}$ is constructed so that $X_{i j}$ shows the value of the $\mathrm{j}^{\text {th }}$ variable for the $\mathrm{i}^{\text {th }}$ decisionmaking unit (see Table 1 below).

Table 1: Decision-making table

\begin{tabular}{c|cccc}
\hline Alternatives & $\mathrm{X}_{1}$ & $\mathrm{X}_{2}$ & $\cdots$ & $\mathrm{X}_{\mathrm{p}}$ \\
\hline $\mathrm{A} 1$ & $\mathrm{X}_{11}$ & $\mathrm{X}_{12}$ & $\cdots$ & $\mathrm{X}_{1 \mathrm{n}}$ \\
$\mathrm{A} 2$ & $\mathrm{X}_{21}$ & $\mathrm{X}_{22}$ & $\cdots$ & $\mathrm{X}_{2 \mathrm{n}}$ \\
$\vdots$ & $\vdots$ & $\vdots$ & $\cdots$ & $\vdots$ \\
$\mathrm{Ak}$ & $\mathrm{X}_{\mathrm{m} 1}$ & $\mathrm{X}_{\mathrm{m} 2}$ & $\cdots$ & $\mathrm{X}_{\mathrm{mn}}$
\end{tabular}

where

$P=$ number of variables $(j=1, \ldots, P)$

$\mathrm{K}=$ number of decision-making units $(\mathrm{i}=1, \ldots, \mathrm{k})$

$X_{m}=\left(X_{1 m}, X_{2 m}, \ldots, X_{k m}\right)(m=1,2, \ldots, p)$

\section{Step 2}

Normalise the variables vectors. If variable has negative impact on performance, then reverse that.

\section{Step 3}

Standardise indices and construct standard matrix of $N_{k x p}$ as shown below:

$N_{i j}=\left(X_{i j-} \mu_{j}\right) / S_{j}$

$N=\left[N_{i j}\right]$

$\mu_{\mathrm{j}}=1 / \mathrm{k} \sum_{j=1}^{k} X_{i j}$

$\mu=\left(\mu_{1}, \mu_{2}, \ldots, \mu_{p}\right) 1 \times p$

where 
$\mu_{j}=$ is the mean of the $\mathrm{j}^{\text {th }}$ variable and $S_{j}$ is the standard deviation of the $\mathrm{j}^{\text {th }}$ variable (column) and $\mathrm{N}$ is the standard matrix.

\section{Step 4}

Calculate the covariance matrix as well as the simple correlation matrix:

$S=\left(S_{j q}\right)_{p \times p}=1 /(k-1)^{*}(X-\mu)^{\top *}(X-\mu) \quad q=1,2, \ldots, p$

$\mathrm{R}=\mathrm{C}_{1} / \sqrt{S_{i j}} \cdot$ S. $\mathrm{C}_{1} / \sqrt{S_{i j}}$

where

$C_{1} / \sqrt{S_{i j}}$ is a pxp diagonal matrix whose $\mathrm{j}^{\text {th }}$ diagonal element is $1 / \sqrt{S_{i j}}$ for $\mathrm{j}=1,2, \ldots, \mathrm{p}$.

\section{Step 5}

Calculate the vector of special values and the special values for correlation. This is calculated using the following equality:

$$
|R-\lambda I p|=0
$$

where $I_{p}$ is the unit square matrix I with $p$ rows and $p$ columns.

Sort special values from the largest to the smallest, and then do the following:

$\lambda_{1}>\lambda_{2}>\ldots . . \lambda_{p}$

$\sum_{j=1}^{p} \lambda_{j}=p$

\section{Step 6}

Develop the $Y_{j}$ components shown below:

$\mathrm{Y}_{\mathrm{m}}=\sum_{j=1}^{p} L m_{j} . . x_{i j} \quad \mathrm{~m}=1,2, \ldots, \mathrm{p} ; \quad \mathrm{i}=1,2, \ldots, \mathrm{k}$

\section{Step 7}

Determine $W_{i}$, the weight of the principal components and scores of principal components for each unit of decision-making, using the following set of formulas:

$\mathrm{W}_{\mathrm{j}}=\lambda_{\mathrm{j}} / \sum_{j=1}^{p} \lambda_{j}=\lambda_{j} / p \quad \mathrm{j}=1,2, \ldots, \mathrm{p}$

$\mathrm{X}_{\mathrm{i}}=\sum_{j=1}^{p} W_{j} . Y_{j} \quad \mathrm{i}=1,2, \ldots, \mathrm{k}$

\section{DATA ANALYSIS}

The vectors of the special values are shown below. Their amounts are obtained using formula (9). After calculating the vector and matrix of special values, and calculating each new component based on the formulas in Step 6, the weights of each component are also calculated, as shown in Table 2. To find the final ranking of these suppliers based upon the lean components, we calculate the scores of each principal component for each unit of decision-making. The results are shown in Table 3. 
Table 2: Special values vectors

\begin{tabular}{|c|c|c|c|c|c|c|c|c|c|c|c|}
\hline $\begin{array}{c}\text { C } \\
\text { (Compo- } \\
\text { nents) }\end{array}$ & $\begin{array}{c}\text { V } \\
\text { (Vectors } \\
\text { of special } \\
\text { values) }\end{array}$ & $\begin{array}{c}\text { W } \\
\text { Weigh } \\
\text { t) }\end{array}$ & C & V & W & C & V & W & C & V & W \\
\hline 1 & 34.25 & 0.4507 & 20 & 0 & 0 & 39 & 0 & 0 & 58 & 0 & 0 \\
\hline 2 & 17.20 & 0.2263 & 21 & 0 & 0 & 40 & 0 & 0 & 59 & 0 & 0 \\
\hline 3 & 10.12 & 0.1332 & 22 & 0 & 0 & 41 & 0 & 0 & 60 & 0 & 0 \\
\hline 4 & 4.52 & 0.0595 & 23 & 0 & 0 & 42 & 0 & 0 & 61 & 0 & 0 \\
\hline 5 & 3.50 & 0.0461 & 24 & 0 & 0 & 43 & 0 & 0 & 62 & 0 & 0 \\
\hline 6 & 1.55 & 0.0204 & 25 & 0 & 0 & 44 & 0 & 0 & 63 & 0 & 0 \\
\hline 7 & 1.21 & 0.0159 & 26 & 0 & 0 & 45 & 0 & 0 & 64 & 0 & 0 \\
\hline 8 & 1.05 & 0.0138 & 27 & 0 & 0 & 46 & 0 & 0 & 65 & 0 & 0 \\
\hline 9 & 0.90 & 0.0118 & 28 & 0 & 0 & 47 & 0 & 0 & 66 & 0 & 0 \\
\hline 10 & 0.60 & 0.0079 & 29 & 0 & 0 & 48 & 0 & 0 & 67 & 0 & 0 \\
\hline 11 & 0.35 & 0.0046 & 30 & 0 & 0 & 49 & 0 & 0 & 68 & 0 & 0 \\
\hline 12 & 0.24 & 0.0032 & 31 & 0 & 0 & 50 & 0 & 0 & 69 & 0 & 0 \\
\hline 13 & 0.15 & 0.0020 & 32 & 0 & 0 & 51 & 0 & 0 & 70 & 0 & 0 \\
\hline 14 & 0.11 & 0.0014 & 33 & 0 & 0 & 52 & 0 & 0 & 71 & 0 & 0 \\
\hline 15 & 0.09 & 0.0012 & 34 & 0 & 0 & 53 & 0 & 0 & 72 & 0 & 0 \\
\hline 16 & 0.08 & 0.0011 & 35 & 0 & 0 & 54 & 0 & 0 & 73 & 0 & 0 \\
\hline 17 & 0.05 & 0.0007 & 36 & 0 & 0 & 55 & 0 & 0 & 74 & 0 & 0 \\
\hline 18 & 0.02 & 0.0003 & 37 & 0 & 0 & 56 & 0 & 0 & 75 & 0 & 0 \\
\hline 19 & 0.011 & 0.0001 & 38 & 0 & 0 & 57 & 0 & 0 & 76 & 0 & 0 \\
\hline
\end{tabular}

$\mathrm{C}=$ Components; $\mathrm{V}=$ Special values; $\mathrm{W}=$ Components' weight

Table 3: Final ranking of suppliers using PCA

\begin{tabular}{|c|c|c|}
\hline Rank & Scores obtained using PCA & Supplier \\
\hline 3 & 0.523 & 1 \\
\hline 5 & 0.268 & 2 \\
\hline 2 & 1.111 & 3 \\
\hline 6 & 0.212 & 4 \\
\hline 8 & 0.125 & 5 \\
\hline 7 & 0.156 & 6 \\
\hline 1 & 1.921 & 7 \\
\hline 4 & 0.321 & 8 \\
\hline
\end{tabular}

\section{CONCLUSION}

Although everyone would like to eliminate all deficiencies and waste in the supply chain, this desire often remains theoretical and does not become a reality. It is possible that all the principles of supply chain cannot achieve complete leanness; but gaining any amount of leanness in the chain can reduce expenses and increase quality, and so satisfy more customers and ensure the survival of the organisation. The lean paradigm requires that 'fat' be eliminated. A lean supply is associated with level scheduling, while information transparency is desirable in any lean regime. While aspects of lean thinking may be appropriate internally for all participants in a supply chain, the ability to extend this way of thinking beyond the boundaries of the firm into the extended supply chain can sometimes be problematic. This is primarily because sometimes the right resources do not exist to allow a lean supply chain management approach to be adopted throughout the chain.

Principal component analysis (PCA) is a mathematical procedure that uses an orthogonal transformation to convert a set of observations of possibly correlated variables into a set of values of uncorrelated variables called principal components. The number of principal components is less than or equal to the number of original variables. PCA is sensitive to the relative scaling of the original variables. Depending on the field of application, it is also named the Hotelling transform or Proper Orthogonal Decomposition (POD). The results of a PCA are usually discussed in terms of component scores (the transformed variable values corresponding to a particular case in the data) and loadings (the weight by which each 
standardised original variable should be multiplied to get the component score). PCA is closely related to factor analysis. True factor analysis makes different assumptions about the underlying structure and solves eigenvectors of a slightly different matrix. PCA is the simplest of the true eigenvector-based multivariate analyses. Often, its operation can be thought of as revealing the internal structure of the data in a way that best explains the variance in the data. If a multivariate dataset is visualised as a set of coordinates in a highdimensional data space ( 1 axis per variable), PCA can supply the user with a lowerdimensional picture, a 'shadow' of this object when viewed from its (in some sense) most informative viewpoint. This is done by using only the first few principal components so that the dimensionality of the transformed data is reduced.

Because suppliers can impact on key organisational issues such as expenses, quality, productivity, effectiveness, and survival, a study of suppliers' performances and rankings is of great value to a company. On the other hand, considering the impact of production leanness on improving an organisation's quality and reducing its expenses, getting materials from lean suppliers may put the company on the right track to reaching its long term goals, drawing more satisfied customers to the company, and ensuring the company's permanent survival. In conclusion, we suggest that any organisation relate closely to lean suppliers, and limit their use of suppliers that appear at the bottom of the leanness list.

\section{REFERENCES}

[1] Ahlstrom, P. \& Karlsson, C. 1996. Change processes towards lean production. The role of the management accounting system. International Journal of Operations and Production Management, 16(11), 42-56.

[2] Azadeh, A., Ghaderi, S.F., Partovi Miran, Y., Ebrahimipour, V. \& Suzuki, K. 2007. An integrated framework for continuous assessment and improvement of manufacturing systems. Applied Mathematics and Computation, 186, 1216-1233.

[3] Barbarosoglu, G. \& Yazgac, T. 1997. An application of the analytic hierarchy process to the supplier selection problem. Production and Inventory Management Journal, 38(1), 14-21.

[4] Bonavia, T. \& Marin, J.A. 2006. An empirical study of lean production in the ceramic tile industry in Spain. International Journal of Operations and Production Management, 26(5), 505-531.

[5] Bruce, M., Daly, L. \& Towers N. 2004. Lean or agile: A solution for supply chain management in the textiles and clothing industry? International Journal of Operations and Production Management, 24(2), $151-170$.

[6] Bruun, P. \& Mefford, R.N. 2004. Lean production and the Internet. Production Economics, 89, 247-260.

[7] Chopra, S. \& Meindle. P. 2001. Supply chain management: Strategy, planning and operation, Prentice Hall.

[8] Current, J. \& Weber, C. 1994. Application of facility location modeling constructs to vender selection problems. European Journal of Operation Research, 26(3), 387-392.

[9] Ettkin, L.P., Raiszadehn, F.M.\& Hunt, H.R. 1990. Just-In-Time: A timely opportunity for small manufacturers. Industrial Management, 32(1), 16-18.

[10] Forrester, P.L., Hassard, J.S. \& Lilley, S. 1996. Pulling it together and pushing it out: People and practices in post-modern production. Proceedings of $2^{\text {nd }}$ International Managing Innovative Manufacturing Conference, Leicester, June.

[11] Ganeshan, R. \& Harrison T.P. An introduction to supply chain management. Penn State University. URL: http:// silmaril.smeal.psu.edu/ misc/ supply_chain_intro.html

[12] Grando, A. \& Sianesi, A. 1996. Supply management: A vendor rating assessment. CEMS Business Review, $1,199-212$.

[13] Hill, R.P. \& Nydick, R.J. 1992. Using the analytic hierarchy process to structure the supplier selection procedure. International Journal of Purchasing and Materials Management, 28(2), 31-36.

[14] Krafcik, J.F. 1988. Triumph of the lean production system. Sloan Management Review, 30(1), 41-52.

[15] Lambert, D.M., Stock, J.R. \& Ellram, L.M. 1998. Fundamentals of logistics management, Boston, MA: Irwin/McGraw-Hill.

[16] Lamming, R. 1996. Squaring lean supply with supply chain management. International Journal of Operations and Production Management, 16(2), 183-196.

[17] Lee, C.Y. 1996. The applicability of just-in-time manufacturing to small manufacturing firms, International Journal of Management, 13 (2), 249-258.

[18] MacDuffie, J.P. 1995. Human resource bundles and manufacturing performance: Organizational logic and flexible production systems in the world auto industry. Industrial and Labor Relations Review, 48(2), 197221. 
[19] Masella, A. 2000. A contingent approach to the design of vendor selection systems for different types of co-operative customer/supplier relationships. International Journal of Operation and Production Management, 20(1), 70-84.

[20] Monden, Y. 1998. Toyota Production System - An integrated approach to just-in-time, $3^{\text {rd }}$ ed. Engineering and Management Press, Norcross, Georgia.

[21] Meier, H.S. \& Forrester, P.L. 2002. A model for evaluating the degree of leanness of manufacturing firms. Integrated Manufacturing Systems, 13(2), 104-109.

[22] Monczko, R., Giunipero, L. \& Reck, R. 1981. Perceived importance of supplier information. International Journal of Purchasing and Materials Management, 17(1), 21-29.

[23] Naylor, J.B., Naim, M.M. \& Berry, D. 1999. Leagility: Integrating the lean and agile manufacturing paradigms in the total supply chain. International Journal of Production Economics, 62, 107-18.

[24] Panizzolo, R. 1998. Applying the lessons learned from 27 lean manufactures: The relevance of relationships management. Production Economics, 55, 223-240.

[25] Ronen, B. \& Trietsch, D. 1998. A decision support system for purchasing management of large projects. Operations Research, 36(6), 882-890.

[26] Shah, R. \& Ward, P.T. 2003. Lean manufacturing: Context, practice bundles, and performance. Journal of Operations Management, 21, 129-149.

[27] Sohal, A.S. \& Egglestone, A. 1994. Lean production: Experience among Australian organizations. International Journal of Operations and Production Management, 14(11), 35-51.

[28] Spekman, R., Kamauff, J. \& Myhr, N. 1998. An empirical investigation into supply chain management: A perspective on partnership. International Journal of Physical Distribution and Logistics Management, 28(8), 630-650.

[29] Scherrer-Rathje, M., Boyle, T.A. \& Deflorin, P. 2009. Lean, take two! Reflections from the second attempt at lean implementation. Business Horizons, 52, 79-88.

[30] Timmerman, E. 1986. An approach to vender performance evaluation. The Journal of Supply Chain Management, 22(4), 2-8

[31] Abdulmalek, F.A. \& Rajgopal, J. 2007. Analyzing the benefits of lean manufacturing and value stream mapping via simulation: A process sector case study. International Journal of Production Economics, 107, 223-236.

[32] Nahmias, S. 2001. Production and operations analysis, $4^{\text {th }}$ ed. McGraw Hill, New York.

[33] Williams, K., Haslam, C., Johal, S., Williams, J., Adcroft, A. \& Willis, R. 1995. Management practice or structural factors: The case of America versus Japan in the car industry. Economic and Industrial Democracy, 16, 9-37.

[34] Womack, J.P. \& Jones, D.T. 1996. Lean thinking, banish waste and create wealth in your corporation, Simon \& Schuster, New York, NY.

[35] Womack, J.P., Jones, D.T. \& Roos, D. 1990. The machine that changed the world. Rawson Associates, New York.

[36] Rossi, F. \& Thomas, A.A. 2001. Analysis of the beverage data using cluster analysis, rotated principal components analysis and LOESS curves. Food Quality and Preference, 12.

[37] Wang, F.K. \& Du T.C.T. 2000. Using principal component analysis in process performance for multivariate data. Omega, 28, 185-194.

[38] Gamesalingam, S. \& Kumar, K. 2001, Detection of financial distress via multivariate statistical analysis. Managerial Finance, 27(4).

[39] Martin, E.B. \& Morris, C. 1999. Kiparissides, manufacturing performance enhance-ment through multivariate statistical process control. Annual Reviews in Control, 23.

[40] Nagai, E. \& Cheng, T.C.E. 1997. Identifying potential barriers to total quality management using principal component analysis and correspondence analysis. International Journal of Quality and Reliability Management, 14(4), 391-408.

[41] Wang, W., Xu, Z. \& Lu, J.W. 2003. Three improved neural network models for air quality forecasting. Engineering Computations, 20(2).

[42] Azadeh, A., Amalnick, M.S., Ghaderi, S.F. \& Asadzadeh, S.M. 2007. An integrated DEA PCA numerical taxonomy approach for energy efficiency assessment and consumption optimization in energy intensive manufacturing sectors. Energy Policy, 35, 3792-3806.

[43] Sugimori, Y., Kusunoki, K., Cho, F. \& Uchikawa, S. 1977. Toyota Production System and Kanban system: Materialization of just-in-time and respect-for-human system. International Journal of Production Research, 15(6), 553-564.

[44] Stevens, G. 1989. Integrating the supply chain. International Journal of Physical Distribution and Materials Management, 19(8) 3-8.

[45] Grunwald, H.J. \& Fortuin, L. 1992. Many steps towards zero inventory. European Journal of Operational Research, 59, 359-369.

[46] Hayes, R.H. \& Pisano, G.P. 1994. Beyond world class: The new manufacturing strategy. Harvard Business Review, January-February, 77-86.

[47] Ohno, T. 1988. Toyota production system: Beyond large-scale production. Productivity Press. 